\title{
Explanation and Use of the Colposcopy Terminology of the IFCPC (International Federation for Cervical Pathology and Colposcopy) Rio 2011
}

\section{Erläuterung und Anwendung der kolposkopischen Nomenklatur der IFCPC (International Federation for Cervical Pathology and Colposcopy) Rio 2011}

Authors

Affiliations
J. Quaas ${ }^{3}$, O. Reich ${ }^{1}$, B. Frey Tirri² ${ }^{2}$ V. Küppers ${ }^{3}$

1 für den Vorstand der Arbeitsgemeinschaft Kolposkopie (AGK, Österreich)

2 für den Vorstand der Arbeitsgemeinschaft für Kolposkopie und Zervixpathologie (AGKOL, Schweiz)

${ }^{3}$ für den Vorstand der Arbeitsgemeinschaft für Kolposkopie und Zervixpathologie (AGCPC, Deutschland)

\section{Key words}

- colposcopy

- cervix uteri

- nomenclature

- IFCPC Rio de Janeiro 2011

Schlüsselwörter

- Kolposkopie

- Cervix uteri

- Nomenklatur

- IFCPC Rio de Janeiro 2011

\section{Bibliography}

DOI http://dx.doi.org/

10.1055/s-0033-1350824

Geburtsh Frauenheilk 2013; 73:

904-907 @ Georg Thieme

Verlag KG Stuttgart - New York . ISSN 0016-5751

\section{Correspondence}

\section{Dr. Jens Quaas}

Sekretär der Arbeitsgemeinschaft Zervixpathologie

\& Kolposkopie

Grünthal 22

18437 Hansestadt Stralsund

dr@jquaas.de

www.ag-cpc.de

\section{Priv.-Doz. Dr. med. Volkmar} Küppers, Facharzt für Frauenheilkunde und Geburtshilfe

Zytologisches Labor -

Dysplasie-Sprechstunde

Königsallee 64

40212 Düsseldorf

info@dysplasie-praxis.de

\section{Abstract \\ $\nabla$}

In July 2012 a revised terminology on colposcopic examinations of the cervix uteri was adopted by IFCPC. Central aspect is a description of characteristics that should aid in the definition of the disease entity cervix uteri. The nomenclature is built up in such a way that the examiner can evaluate colposcopic criteria according to a specific scheme. Firstly it is assessed whether the colposcopy is representative. Then it should be clarified whether or not the findings are normal. If the findings are not normal but rather abnormal the severity of the lesion is classified according to the so-called grade 1 (minor change) and grade 2 findings (major change). Specific abnormal findings such as leukoplakia, erosion and Lugol's finding are also not defined at this point. Characteristics suspicious for an invasion are described separately, in particular, atypical vessel patterns are mentioned here. As already held in the previous revised nomenclature (Barcelona), various findings are described in a last group: congenital transformation zones (CTZ), congenital anomalies, condylomas (papillomas), endometriosis, polyps (ectocervical, endocervical), inflammation, stenosis, postoperative changes (scarred portio, vaginal stump).

\section{Introduction}

The new and thus currently valid coloscopic nomenclature was published on 1 July 2012 in the journal "Obstetrics \& Gynecology" [1]. This had been preceded by the appointment of a nomenclature committee in 2008 on the occasion of the world congress in Oakland, New Zealand.

After extensive literature searches, several meetings and detailed discussions in the website of

\section{Zusammenfassung \\ $\nabla$}

Im Juli 2012 wurde eine überarbeitete Nomenklatur zur kolposkopischen Untersuchung der Cervix uteri durch die IFCPC verabschiedet. Im Mittelpunkt steht die Beschreibung von Merkmalen, die helfen sollen, Krankheitsbilder an der Cervix uteri zu definieren. Die Nomenklatur ist so aufgebaut, dass der Untersucher nach einem bestimmten Schema kolposkopische Kriterien beurteilt. Zunächst wird geprüft, ob die Kolposkopie repräsentativ ist. Dann soll geklärt werden, ob ein Normalbefund vorliegt. Liegen keine Normalbefunde, sondern abnorme Befunde vor, wird die Schwere der Läsion in sog. Grad-1- (minor change) und Grad-2-Befunde (major change) festgelegt. Es werden auch nicht spezifische abnorme Befunde - die Leukoplakie, die Erosion und die Lugol-Probe - definiert. Gesondert werden Merkmale beschrieben, die verdächtig auf eine Invasion sind, insbesondere wird hier auf die atypischen Gefäßmuster hingewiesen. Wie schon in der letzten überarbeiteten Nomenklatur (Barcelona) werden in einer letzten Gruppe verschiedene Befunde beschrieben: kongenitale Transformationszone (KTZ), kongenitale Anomalie, Kondylome (Papillome), Endometriose, Polypen (ektozervikal, endozervikal) Entzündung, Stenose, postoperative Veränderung (vernarbte Portio, Scheidenblindsack).

IFCPC, the new version of the nomenclature was accepted at the world congress in Rio de Janeiro in July 2011.

The new nomenclature 2011 consists of 3 parts: 1. Nomenclature concerning the cervix uteri ( Tab. 1) including an appendix on the definition of types of excision ( Table 2 ).

2. Nomenclature for the vagina.

3. Nomenclature for the vulva which was formulated in cooperation with the International So- 
Table 1 Colposcopic nomenclature of cervix uteri (IFCPC 2011), after [9].

\begin{tabular}{|c|c|c|}
\hline $\begin{array}{l}\text { IFCPC } \\
2011\end{array}$ & $\begin{array}{l}\text { Rio de } \\
\text { Janeiro }\end{array}$ & $\begin{array}{l}\text { Colposcopic nomenclature } \\
\text { for cervix uteri }\end{array}$ \\
\hline General: & & $\begin{array}{l}\text { adequate/inadequate: reason: } \\
\text { (e.g., inflammation, bleeding, scars) } \\
\text { columnar - squamous epithelium - border } \\
\text { (CSB): completely/partially/not visible } \\
\text { transformation zone (type } 1,2,3 \text { ) }\end{array}$ \\
\hline $\begin{array}{l}\text { Normal } \\
\text { finding }\end{array}$ & & $\begin{array}{l}\text { original squamous epithelium: } \\
\text { / mature } \\
\text { - atrophic } \\
\text { columnar epithelium } \\
\text { - ectopy } \\
\text { metaplastic squamous epithelium } \\
\text { ovula Nabothii } \\
\text { - excretory ducts of glands } \\
\text { deciduosis in pregnancy }\end{array}$ \\
\hline \multirow[t]{4}{*}{$\begin{array}{l}\text { Abnormal } \\
\text { finding }\end{array}$} & general: & $\begin{array}{l}\text { localisation of the lesion: } \\
\text { inside or outside the epithelium, } \\
\text { given according to clock face } \\
\text { size of the lesion: } \\
\text { number of affected quadrants } \\
\text { percent of the cervix }\end{array}$ \\
\hline & $\begin{array}{l}\text { grade } 1 \\
\text { (minor } \\
\text { change) }\end{array}$ & $\begin{array}{l}\text { delicate acetic-white epithelium, } \\
\text { delicate mosaic, delicate puncturing }\end{array}$ \\
\hline & $\begin{array}{l}\text { grade } 2 \\
\text { (major } \\
\text { change) }\end{array}$ & $\begin{array}{l}\text { intensive acetic-white epithelium } \\
\text { coarse mosaic, coarse puncturing } \\
\text { prominent excretory ducts of glands } \\
\text { sharp borders } \\
\text { inner border sign, ridge sign } \\
\text { rapid acetic acid reaction }\end{array}$ \\
\hline & $\begin{array}{l}\text { not } \\
\text { specific }\end{array}$ & $\begin{array}{l}\text { leukoplakia (keratosis, hyperkeratosis), } \\
\text { erosion } \\
\text { Lugol's reaction (Schiller test) }\end{array}$ \\
\hline $\begin{array}{l}\text { Suspected } \\
\text { invasion }\end{array}$ & & $\begin{array}{l}\text { atypical vessels } \\
\text { additional findings: vessels that bleed on } \\
\text { contact, irregular surfaces, exophytic lesion, } \\
\text { necrosis, ulcer, tumour }\end{array}$ \\
\hline $\begin{array}{l}\text { Miscellane- } \\
\text { ous findings }\end{array}$ & & $\begin{array}{l}\text { congenital transformation zones (CTZ), } \\
\text { congenital anomalies, condylomas (papillo- } \\
\text { mas), endometriosis, polyps (ectocervical, } \\
\text { endocervical) } \\
\text { inflammation, stenosis, postoperative } \\
\text { changes (scarred portio, vaginal stump) }\end{array}$ \\
\hline
\end{tabular}

ciety for the Study of Vulvovaginal Diseases (ISSVD). These were published in a second publication.

The aim of the following explanations is to create a relationship between the new nomenclature and the daily routine of colposcopic examinations.

At the same time, the authors want to point out that a common foundation for the use of the now internationally valid colposcopic nomenclature of cervix uteri in the German-speaking countries has been published [9].The boards of AGK, AGCPC and AGKOL have thus recognised the validity of the colposcopic nomenclature 2011 and recommend their members to use them in their daily routine.

We appeal to all interested colleagues to send their comments and ideas to their management boards. These will then be introduced at the next meeting of the nomenclature commission of the IFCPC.
Table 2 Addendum to colposcopic nomenclature for cervix uteri (IFCPC 2011), after [9].

$\begin{array}{ll}\begin{array}{l}\text { IFCPC } \\ 2011\end{array} & \begin{array}{l}\text { Colposcopic nomenclature } \\ \text { type } 1 \text { - flat } \\ \text { type } 2 \text { - medium } \\ \text { type 3 - steep } \\ \text { height (length): } \\ \text { distance from cervical to vaginal } \\ \text { resection border (see Fig. below) } \\ \text { width: } \\ \text { distance from stromal resection } \\ \text { of conisation } \\ \text { specimens }\end{array}\end{array}$

It should be emphasised that the aim of the nomenclature commission is to develop an evidence-based terminology. It is also apparent that the commitment of the IFCPC was to promote a closer relationship to therapeutic procedures. Examples of this are the introduction of a grading for the visibility of the columnar-squamous epithelium boundary and the types of excision mentioned in the appendix ( $\bullet$ Table 2 ). In the authors' opinion this step is to be welcomed as it leads to a clearer position with regard to individualised therapy planning and performance. See also the corresponding German-language groundwork (e.g., Kühn 2011 [7], Kühn et al. 2012 [8]). Overall, the new colposcopic nomenclature more clearly emphasises the significance of colposcopic examinations than did the preceding version.

Especially gratifying is the fact that two current publications from Germany-speaking countries (Scheungraber et al. $[3,4]$ ) have been duly incorporated in the revision of the nomenclature. It should also be mentioned that the practically important differentiation between the localisation of lesions inside and outside of the transformation zones has been explicitly described in the nomenclature and also that the significance of the surface expansion of dysplasia in cervix uteri has been scientifically confirmed by publications from German-speaking countries [10,11].

In the following paragraphs those aspects are mentioned that have changed in comparison to the previously valid terminology (Barcelona 2002 [6]) or, respectively have been included for the first time. 


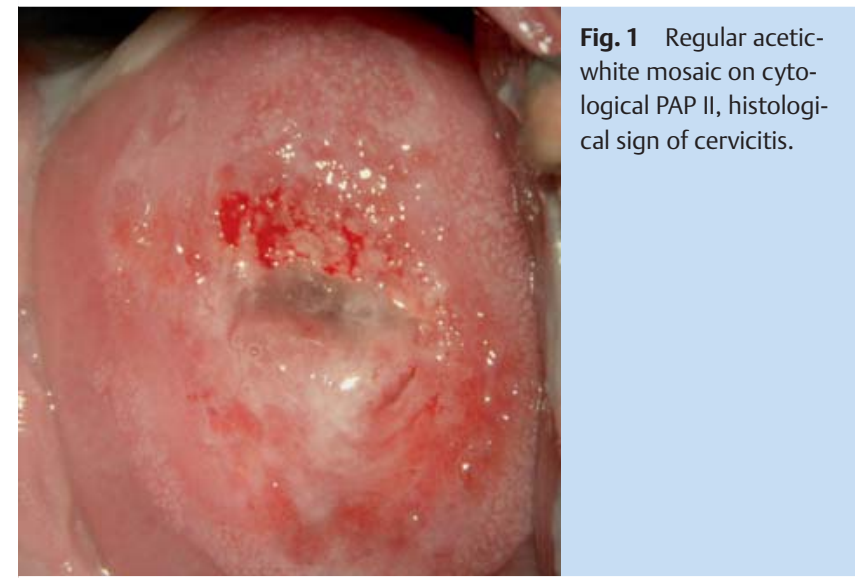

\section{Nomenclature of Cervix Uteri}

$\nabla$

Some basic preliminary remarks of fundamental importance need to be made about the colposcopic nomenclature for cervix uteri and the vagina. Is the colposcopic examination "adequate"

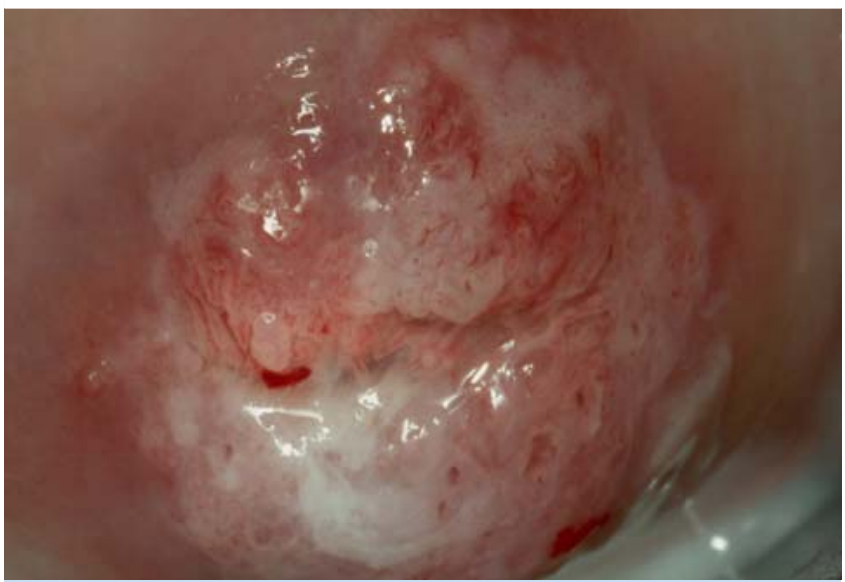

Fig. 2 Opaque acetic-white epithelium on the anterior lip of the cervical os at 12 o'clock with coarse mosaic (major change), transformation zone 1.

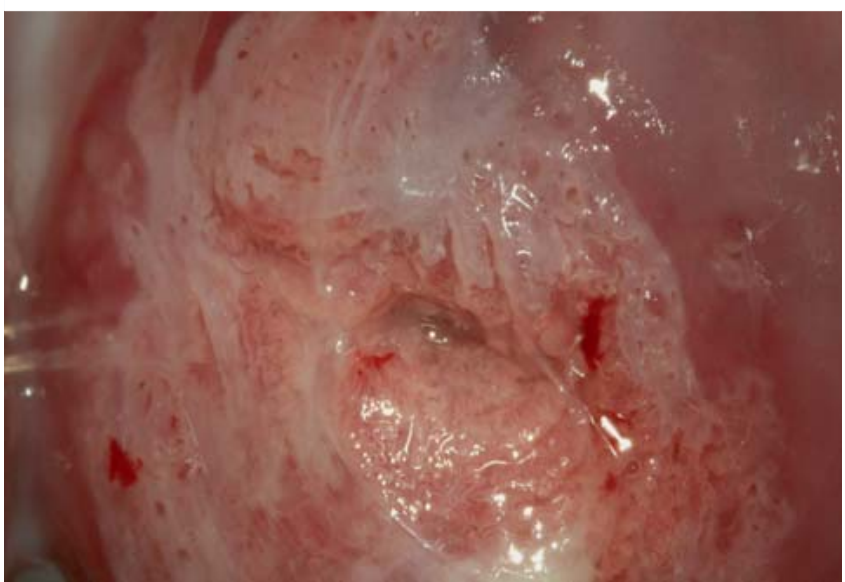

Fig. 4 Pronounced acetic-white epithelium on the anterior lip of the cervical os with typical "ridge sign" (major change) in histologically confirmed CIN 3, transformation zone 1. or "inadequate with reasons"? This replaces the term "satisfactory/unsatisfactory colposcopy". This change should emphasise that in the case of an inadaquate coposcopy due to, e.g., inflammation, a control examination has to be performed after therapy. Moving the evaluability and general significance of a colposcopic examination to the beginning of the nomenclature emphasises the relative values.

This applies especially to the visualisation of the columnar-squamous epithelium border and thus the classification of the transformation zones into types $1-3$. The two classifications certainly overlap but represent two differerent aspects. The columnarsquamous epithelium border is the "inner" border for the transformation zone (mature columnar epithelium border) and can, accordingly, be "completely", "partially" or even "not visible". In the transformation zones 1 and 2 the columnar-squamous epithelium border is completely visible. As mentioned above it was the intention of the IFCPC nomenclature committee to make the planning of possibly necessary therapeutic options better. Evaluation of the above two aspects does make this better, e.g., for the targeted excision of abnormal areas (excision type).

For normal findings, an extension has also been made: atrophic squamous epithelium, changes in pregnancy (deciduosis) and

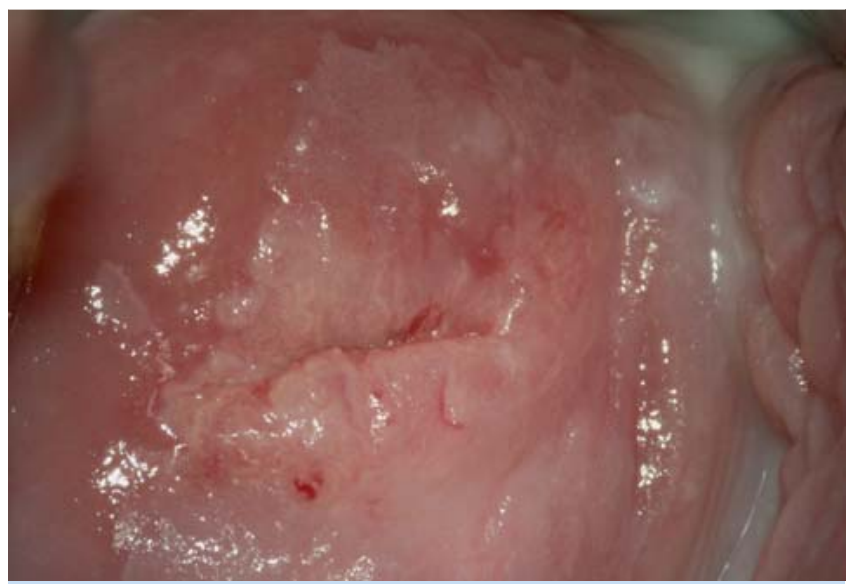

Fig. 3 Pronounced acetic-white epithelium with "inner border" at 1 o'clock ectocervical in histologically confirmed CIN 2.

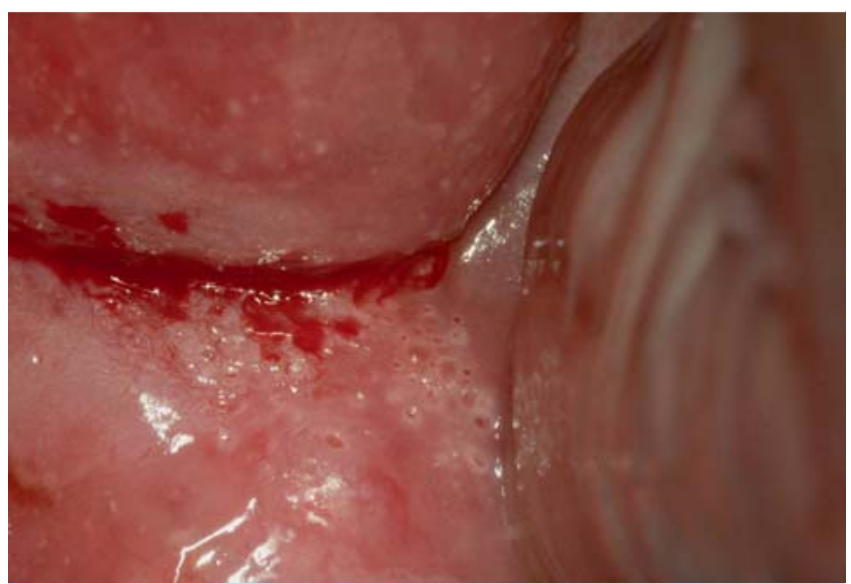

Fig. 5 Acetic-white elevated mound of excretory ducts of the cervical gland on the posterior lip of the cervical os (major change) in histologically confirmed CIN 3. 
metaplasia. It should be noted critically that making the diagnosis of metaplasia actually necessitates a prior histological clarification in order to prove the existence of the metaplasia and exclude other functional findings, e.g., hyperplastic or polypous ectopy.

In abnormal colposcopic findings, the localisation of the lesion inside or outside the transformation zone - has been re-included in the nomenclature and supplemented with the terms "inner border" (border within the acetic-white epithelium) and "ridge sign" $[3,4]$.

The size of the lesion has been incorporated in the nomenclature whereby the dimensions of the lesion are to be given as number of afflicted quadrants or, respectively, as percentage of the cervix. The grading into "minor" and "major changes" that was already defined in the Rome 1991 nomenclature [5] has been retained. "Minor changes" can also be described as grade 1 changes ( Fig. 1) and "major changes" as grade 2 changes ( $\bullet$ Figs. 2 to 5 ). Newly taken into consideration is the interpretation of the dynamics of the acetic acid reaction in cervix uteri. It is pointed out that a rapid and intensive, positive acetic acid reaction must be classified as "major changes". It should be noted that the slow development of a positive acetic acid reaction, which in individual cases may require a reaction time of up to 3 minutes, belongs to the "major changes" when the other "major change" criteria are applicable.

As already mentioned in the introduction, the committee could not agree to classify the term leukoplakia into the groups of minor or, respectively, major changes. Leukoplakia, erosion and Lugol's reaction (Schiller test) are classified as "non specific". In particular, the classification of Lugol's reaction as an unspecific examination method emphasises the necessity of the preoperative application of an acetic acid text. Lugol's reaction alone is not a suitable measure for the preoperative planning of the excision line.

An extension is found in cases of suspected invasion in that atypical vessels are now merely defined as invasion characteristics in contrast to previous neomclature suggestions. So far atypical vessels were assigned to the "major change" lesions. In addition, further clinical aspects have been incorporated such as, for example, vessels that bleed upon contact.

Under the so-called miscellaneous findings we now find the "congenital transformation zone, CTZ" and postoperative changes such as "scarred portio" (after conisation) or "vaginal stump". An exact description of the term CTZ is still lacking and will be subject of further discussion in the IFCPC nomenclature commission.

\section{Addendum: Excision Types and Conisation Specimens \\ $\nabla$}

Three different excision types and also the dimensions of conisation specimens have been added as an addendum ( 0 Table 2 ). The excision types represent a practical relationship to the types of transformation zones and are intended to replace the further use of widely differing excision terms by descriptions of the excisions performed and not the methods themselves.

\section{Conflict of Interest}

$\nabla$

None.

\section{References}

1 Bornstein J, Bentley J, Bösze P et al. 2011 colposcopic terminology of the International Federation for Cervical Pathology and Colposcopy. Obstet Gynecol 2012; 120: 166-172

2 Bornstein J, Sideri M, Tatti S et al. 2011 terminology of the vulva of the International Federation for Cervical Pathology and Colposcopy. J Low Genit Tract Dis 2012; 16: 290-295

3 Scheungraber C, Glutig K, Fechtel B et al. Inner border-a specific and significant colposcopic sign for moderate or severe dysplasia (cervical intraepithelial neoplasia 2 or 3). J Low Genit Tract Dis 2009;13: 1-4

4 Scheungraber C, Koenig $U$, Fechtel B et al. The colposcopic feature ridge sign is associated with the presence of cervical intraepithelial neoplasia $2 / 3$ and human papillomavirus 16 in young women. J Low Genit Tract Dis 2009; 13: 13-16

5 Stafl A, Wilbanks GD. An international terminology of colposcopy: report of the nomenclature committee of the International Federation of Cervical Pathology and Colposcopy. Obstet Gynecol 1991; 77: 313 314

6 Quaas J, Petry K-U, Heinrich J. Darstellung und Erläuterungen zur aktuellen kolposkopischen Nomenklatur Barcelona 2002. Geburtsh Frauenheilk 2007; 67: 1324-1327

7 Kühn W. Kolposkopie zur Früherkennung des Zervixkarzinoms. Pathologe 2011; 32: 497-495

8 Kühn W, Cichon G, Schneider A. Morphologische Aspekte zu frühgeburtsvermeidenden Konisationstechniken. gyn 2012; 17: 262-268

9 Girardi F, Frey Tirri B, Küppers V et al. Neue kolposkopische IFCPC-Nomenklatur der Cervix uteri (Rio de Janeiro 2011). Frauenarzt 2012; 53: 1064-1065

10 Burghardt E, Pickel H, Girardi F. Colposcopy-cervical Pathology. 3rd ed. Stuttgart: Thieme; 1998

11 Fritsch H, Hoermann R, Bitsche $M$ et al. Development of epithelial and mesenchymal regionalization of the human fetal utero-vaginal anlagen. J Anat 2013; 222: 462-472

Deutschsprachige Zusatzinformationen online abrufbar unter: www.thieme-connect.de/ejournals/toc/gebfra. 